\title{
Pontobulbar palsy and neurosensory deafness (Brown-Vialetto-Van Laere syndrome) with possible autosomal dominant inheritance
}

\author{
S A Hawkins, N C Nevin, A E Harding
}

\begin{abstract}
A female with the Brown-Vialetto-Van Laere syndrome is described. The patient's father, a paternal uncle, and possibly a paternal first cousin had neurosensory deafness and a paternal aunt had clinical symptoms indicative of the syndrome. This family raises the possibility that the disorder is genetically heterogeneous with autosomal recessive and autosomal dominant forms. Alternatively, it could be caused by a mutant gene on the $X$ chromosome.
\end{abstract}

The Brown-Vialetto-Van Laere syndrome is a rare condition characterised by bilateral nerve deafness accompanied by cranial nerve disorders, usually involving the motor components of the seventh, and ninth to twelfth nerves. ${ }^{1-5}$ In some cases, there is involvement of the spinal motor nerves and less commonly of upper motor neurones. The onset of the disease is usually in childhood. Although most reported cases are sporadic, ${ }^{135-10}$ familial cases have been described. ${ }^{2} 1112$

The present paper describes an affected girl whose father and a paternal uncle had bilateral neurosensory deafness, and whose paternal aunt had bilateral neurosensory deafness and muscle weakness. It is suggested in this family that inheritance may be autosomal dominant or, alternatively, $\mathrm{X}$ linked.

Department of Medicine, The Queen's University of Belfast.

S A Hawkins

Department of Medical Genetics, The Queen's University of Belfast, Floor A, Belfast City Hospital, Lisburn Road, Belfast BT9 7AB.

N C Nevin

University Department of Clinical Neurology, Institute of Neurology, Queen Square, London WC1N 3BG.

A E Harding

Correspondence to Professor Nevin.

Received for publication 4 September 1989

Accepted for publication 28 September 1989.

\section{Case report}

The proband was born at term after a normal delivery. There was no history of adverse factors during the antenatal period. Development was normal. She was a healthy, athletic young girl who was a good swimmer with no neuromuscular problems before the onset of her illness. At the age of 12 years, over the course of a few weeks, she experienced rapid onset neurosensory deafness. The following year she developed rapidly progressive weakness with clumsiness of her upper limbs and difficulty in washing, dressing, writing, and combing her hair. At that time her mother noted she tended to shake and twitch particular at night. During the day she was sleepy. She also complained of shortness of breath. It was also noticed that she was unable to rise from lying, her speech was soft, and she had difficulty with swallowing.

When aged $131 / 2$ years, she was treated with steroids for 12 months, during which time her condition improved. When she was 15 years old she began to deteriorate again. On clinical examination of the cranial nerves the fields of vision were full and the pupillary responses were normal. The optic discs were pale but the optic fundi were normal. Visual acuity was normal. The external ocular movements were full. There was no ptosis. There was unsustained nystagmus on lateral gaze. The corneal responses were present. The jaw jerk was not obtained. There was weakness of the orbicularis oculi but muscles around the mouth had normal power. There was severe neurosensory deafness. The gag reflex was normal. The sternomastoid muscles were weak. The tongue was was small, wasted, and fasciculating.

There was marked wasting of the muscles of the hands and forearms, more severe distally (MRC grade 2 ) than proximally (MRC grade 3/4). Power in the legs was grade 4- proximally and normal distally. The tendon reflexes were sluggish in the upper limbs and pathologically brisk in the legs. The plantar responses were extensor. There was no ataxia. She had diaphragmatic weakness and an exaggerated lumbar lordosis (fig 1).

INVESTIGATIONS

The following investigations gave normal values: full 
blood count, serum electrolytes, urea, glucose, creatine kinase, ESR, chest $x$ ray, ECG, and CT scan. The karyotype was $46, \mathrm{XX}$. The CSF protein was $0.8 \mathrm{mg} / \mathrm{l}$. EEG showed slight excess of theta activity. Visual evoked responses showed Pl latency of 110 msecs on the right and 125 msecs on the left, the amplitudes being 9 and $15 \mu \mathrm{V}$ respectively. Sensory evoked

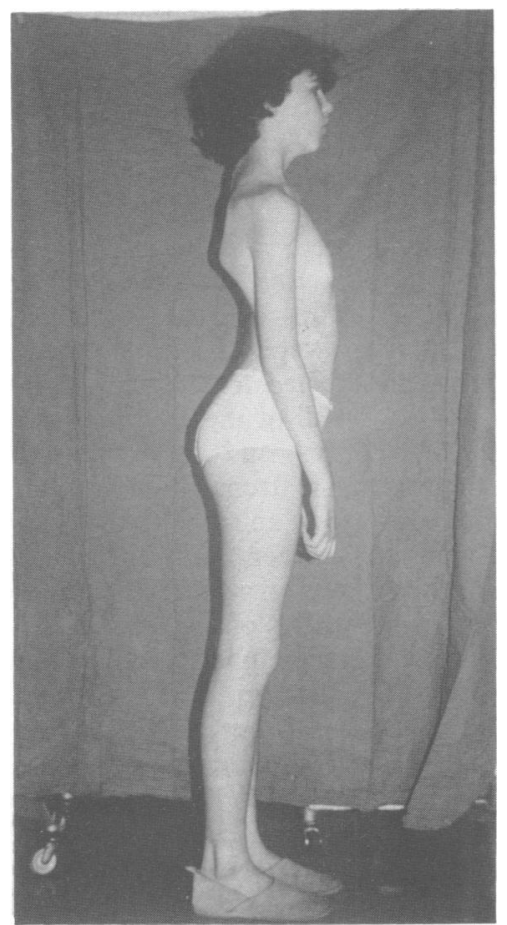

Figure 1 The patient at $131 / 2$ years showing exaggerated lumbar lordosis. responses were normal. Auditory evoked responses showed that waves 1,2 , and 3 were normal but waves 4 and 5 were absent. Flash retinograms were normal. Nerve conduction velocities were in the normal range at $50 \mathrm{~m} / \mathrm{sec}$ and $53 \mathrm{~m} / \mathrm{sec}$ in the right median and tibial nerves respectively. In the right peroneal nerve the conduction velocity was $38 \mathrm{~m} / \mathrm{sec}$. The electromyogram showed features of mild denervation. A muscle biopsy showed neurogenic changes with severe atrophy of type I fibres, with a tendency towards grouping of small fibres and interstitial fibrosis. Ultrastructural examination showed wide variation in fibre diameter with many atrophied fibres surrounding hypertrophied fibres. Central nuclei were occasionally seen within the smaller fibres. A sural nerve biopsy was normal. Respiratory function tests showed an impaired forced vital capacity which on standing was 21 (64\% of predicted value), on sitting was $1.81(57 \%)$, and on lying was $1.41(44 \%)$. Her Astrup showed evidence of respiratory failure: pH 7.34, $\mathrm{PcO}_{2} 59 \mathrm{~mm} / \mathrm{Hg}$, and base excess $5 \cdot 2$. Standard bicarbonate was 28.8 and $\mathrm{PO}_{2}$ was 73 $\mathrm{mm} / \mathrm{Hg}$ indicating a partially compensated respiratory acidosis with marked hypoxia.

\section{PROGRESS}

She had diaphragmatic weakness causing nocturnal hypoventilation (confirmed on sleep study), respiratory failure, and daytime sleepiness. At the age of 16 years, arrangements were made for her to have assisted ventilation using a Tunnicliffe jacket. Initially, the nocturnal assisted ventilation was beneficial and she was more alert. Although her general level of energy improved, there was no measurable improvement in muscle power.

She had several episodes of respiratory infection for

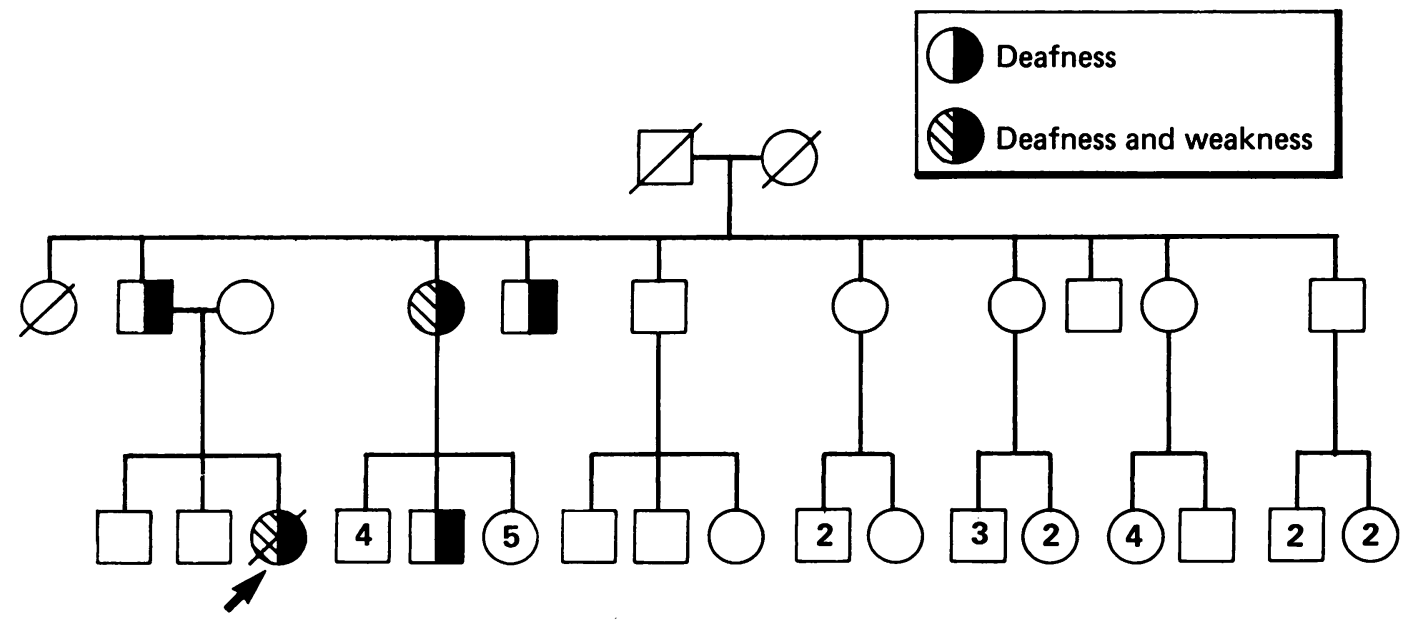

Figure 2 Family pedigree. 
which she required assisted ventilation during the day as well as at night. The muscle weakness progressed with marked weakness in the sternomastoid muscles. She had a right vocal cord paralysis. Swallowing became progressively difficult and weight loss was marked. She died aged 17 years 4 months. Permission for necropsy was refused.

\section{Family history}

The parents were not consanguineous. At the age of 8 years, her father (fig 2, II.2) developed nerve deafness. Clinically he had no evidence of neuromuscular disease. He was the second of a sibship of 10. A younger brother (II.4) and a younger sister (II.3) also had neurosensory deafness. For 20 years the sister had breathing difficulties and for two years facial weakness. Clinically, she had pallor of the left optic disc and visual acuities of $6 / 36$ bilaterally. She had weakness of the facial and neck muscles and neurosensory deafness. The tongue was wasted and fasciculating. No weakness was detected in the limbs and all reflexes were preserved. The diaphragm was weak. Unfortunately, she refused further investigation and permission to examine her 10 children. A school doctor reported that one of her sons had developed neurosensory deafness in his teens. The paternal grandfather (I.1) died aged 40 years with chronic respiratory problems. According to the family he had never had any hearing difficulties.

\section{Discussion}

The clinical neurological findings of neuronal deafness, wasting and weakness of the tongue and neck muscles, lower motor neurone signs in the upper limbs, upper motor neurone signs in the lower limbs, and diaphragmatic weakness point to a lesion in the lower brain stem and cervical spinal cord. The sudden onset of deafness, the subsequent cranial nerve weakness, the progressive muscle weakness, and the respiratory difficulties suggested the possible diagnosis of pontobulbar palsy with neurosensory deafness
(Brown-Vialetto-Van Laere syndrome). This is a rare syndrome. In 1981 Gallai et al $^{12}$ described two cases and the clinical course and necropsy findings in a sib of one of the two cases who had died in infancy with a similar condition. They also reviewed the 17 previously published cases. In every reported case the first clinical symptom has been bilateral neurosensory deafness of slow or rapid onset. In most cases this was followed within a few years by lower cranial motor nerve palsies. The subsequent clinical course varied greatly from case to case.

In four or possibly five families two or more sibs were affected (table). Vialetto ${ }^{2}$ described an affected female who had three affected sisters and a normal brother. In the family reported by Van Laere ${ }^{3}$ an affected female had four affected sisters. The family described by. Boudin et al $^{11}$ had two affected female sibs and in the sibship reported by Gallai et $a^{12}$ a brother and a sister were affected. Lombaert et $a l^{9}$ also described an affected female whose brother was possibly affected. In all of these families the parents were clinically normal and there were no other affected subjects apart from those in the sibship. These pedigrees support an autosomal recessive mode of inheritance. In another family reported by Van Laere $^{3}$ the proband was an affected male and deafness was present on both sides of the family.

In the present family inheritance could be autosomal dominant. The proband had an affected paternal aunt and her father, a paternal uncle, and possibly a paternal first cousin had neurosensory deafness. It is possible that some persons with the gene may not be severely affected. Some families have been described in which very mildly affected patients have been reported only because of more severely affected sibs. ${ }^{2}$

There is a preponderance of reports in which the affected subjects are females, and the male reported by Gallai $e t a^{12}$ was much more severely affected than his sister. It is also possible that this disorder is $\mathbf{X}$ linked, with occasional lethality in affected males. Although case II.2 in the present kindred had deafness alone, there was no male to male transmission.

Familial reports of the Brown-Vialetto-Van Laere syndrome.

\begin{tabular}{|c|c|c|c|c|}
\hline Authors & Case No & Sex & Family history & Inheritance \\
\hline Vialetto $^{2}$ & 1 & $\mathbf{F}$ & $\begin{array}{l}3 \text { affected sisters } \\
\text { and a normal brother }\end{array}$ & $\mathbf{A R}$ \\
\hline $\begin{array}{l}\text { Van Laere }{ }^{3} \\
\text { Van Laere }\end{array}$ & $\begin{array}{l}2 \\
1 \\
1\end{array}$ & $\begin{array}{l}\mathbf{F} \\
\mathbf{F} \\
\mathbf{F}\end{array}$ & $\begin{array}{l}9 \text { sibs died young } \\
4 \text { sisters affected } \\
\text { Deafness on both sides } \\
\text { of the family }\end{array}$ & $\begin{array}{l}? \\
\text { AR } \\
?\end{array}$ \\
\hline $\begin{array}{l}\text { Lombaert et al } \\
\text { Boudin et } a l^{11}\end{array}$ & $\begin{array}{l}1 \\
1\end{array}$ & $\begin{array}{l}\mathbf{F} \\
\mathbf{F}\end{array}$ & $\begin{array}{l}\text { ? brother affected } \\
\text { Cases } 1 \text { and } 2 \text { affected } \\
\text { sisters }\end{array}$ & $\begin{array}{l}\mathbf{A R} \\
\mathbf{A R}\end{array}$ \\
\hline Gallai et $a l^{12}$ & $\begin{array}{l}2 \\
1 \\
2\end{array}$ & $\begin{array}{l}\mathbf{F} \\
\mathbf{F} \\
\mathbf{M}\end{array}$ & Cases 1 and 2 sibs & $\mathbf{A R}$ \\
\hline
\end{tabular}


1 Brown CH. Infantile amyotrophic lateral sclerosis of the family type. F Nerv Ment Dis 1894;21:707-16.

2 Vialetto E. Contributo alla forma ereditaria della paralisi bulbare progressiva. Riv Sper Freniat 1936;40:1-24.

3 Van Laere J. Paralysie bulbo-pontine chronique progressive familiale avec surdité. Un cas de syndrome de KlippelTrenaunay dans la même fratrie. Problèmes diagnostiques et génétiques. Rev Neurol (Paris) 1966;115:289-95.

4 Van Laere J. Over een nieuw geval van chronische bulbopontiene paralysis met doofheid. Vehr Vlaam Akad Geneeskd Belg 1967;30:288-308.

5 Van Laere J. Un nouveau cas de paralysie bulbo-pontine chronique progressive avec surdité. Rev Neurol (Paris) 1977;33: 119-24.

6 Arnould G, Tridon P, Laxenaire M, Picard L, Weber M, Brichet B. Paralysie bulbo-pontine chronique progressive avec surdité. A propos d'une observation de syndrome de Fazio-Londe. Rev Oioneuroophthalmol 1968;40:158-61.
7 Trillet M, Girrard PF, Schott B, Ramel P, Woehrle R. La paralysie bulbo-pontine chronique progressive avec surdité (à propos d'une observation clinique). Lyon Med 1970;223:145-53.

8 Serratrice G, Gastaut JL. Amyotrophies degeneratives et lésion du neurone moteur (à propos de 32 observations). Marseille Med 1972;109:821-40.

9 Lombaert A, Dom R, Carton H, Brucher JM. Progressive pontobulbar palsy with deafness-a clinico-pathological study. Acta Neurol Belg 1976;76:309-14.

10 Alberca R, Montero C, Ibañez A, Segura DI, Miranda-Nieves G. Progressive bulbar paralysis associated with neural deafness-a nosological entity. Arch Neurol 1980;37:214-21.

11 Boudin G, Pépin B, Vernant JC, Gautier B, Gouérou B. Cas familial de paralysie bulbo-pontine chronique progressive avec surdité. Rev Neurol (Paris) 1971;124:90-2.

12 Gallai V, Hockaday JM, Hughes JT, Lane DJ, Oppenheimer DR, Rushworth G. Ponto-bulbar palsy with deafness (BrownVialetto-Van Laere syndrome). F Neurol Sci 1981;50:259-75. 